\begin{tabular}{|l|l|l|l|}
\hline Eiszeitalter u. Gegenwart & 35 & $\begin{array}{c}9-13 \\
1 \mathrm{fig} .\end{array}$ & Hannover 1985 \\
\hline
\end{tabular}

\title{
A Dated Holocene Sediment Core from the Bottom of the Southern North Sea
}

\author{
Karl-ERnst Behre, JÜrgen DörJes \& Georg Irion *)
}

Marine environment, core, Ocean floors, holocene mollusc communities, heavy metal pollution, minerals, postglacial vegetations history, reconstruction, paleoecology, pollen, late Boreal, sea level changes, transgression.

Southern North Sea

A b s t r a c t : A core from the southern North Sea $\left(53^{\circ} 44,5^{\prime} \mathrm{N}, 4^{\circ} 30^{\prime} \mathrm{E}\right)$ was investigated for pollen, macro-remains, malacozoology, minerals and heavy metals. The freshwater peat and mud were identified as basis peat in the genetic sense, they are followed by brackish and marine sediments without erosion in between. The position of the transgression contact is at $42.5 \mathrm{~m}$ below mean sea-level and was dated to the late Boreal period (about 8150 years BP). Until the Atlantic period the location of profile A 521 was situated close to the coast in shallow waters. After a long hiatus in time $1.8 \mathrm{~m}$ of deep water sediments (Younger Sea Sand) follow, which were deposited presumably since medieval time. In the uppermost metre of these young sediments a strong increase of heavy metals can be shown, which is referred to anthropogenic water pollution, starting at about the year $1880 \mathrm{AD}$.

[Ein datierter holozäner Sedimentkern vom Grund der südlichen Nordsee]

$\mathrm{K}$ u r z f a s s u n g : Ein Bohrkern aus der südlichen Nordsee $\left(54^{\circ} 44,5^{\prime} \mathrm{N}, 4^{\circ} 30^{\prime} \mathrm{E}\right)$ wurde auf Pollen, botanische Makroreste, Mollusken sowie Minerale und Schwermetalle untersucht. Im Liegenden befindet sich ein echter Basistorf, auf den ohne Erosion Süßwasser-, Brackwasser- und Salzwassersedimente folgen. Der Transgressionskontakt liegt bei $42,5 \mathrm{~m}$ unter Mittelwasser und wurde auf spätes Boreal (etwa 8150 Jahre BP.) datiert, die Profilstelle blieb bis ins Atlantikum im ufernahen Flachwasserbereich. Es folgen nach einem langen zeitlichen Hiatus junge Tiefwassersedimente, die seit oder nach dem Mittelalter abgelagert worden sind. Im obersten Meter steigt der Schwermetallgehalt stark an, was mit der anthropogenen Verschmutzung seit $1880 \mathrm{AD}$ begründet wird.

\section{Introduction}

Up till now the number of fixed points for the curve of the holocene transgression is very small, even in the North Sea area. Most of the dates come from borings in the

*) Addresses of the authors: Prof. Dr. K.-E. BEHRE, Niedersächsisches Landesinstitut für Marschen- und Wurtenforschung, Viktoriastr. 26/28, D - 2940 Wilhelmshaven. Dr. J. DörJes, Dr. G. IRION, Forschungsinstitut Senckenberg, Abteilung für Meeresgeologie und Meeresbiologie, Schleusenstr. 39A, D - 2940 Wilhelmshaven. 
coastal areas and therefore concern only the younger part of the sea-level curve. In order to get more information on the earlier phases of the Flandrian transgression a joint program was started by the two institutes in Wilhelmshaven to detect suitable peat layers on the bottom of the Southern North Sea. Close cooperation between geobotany, zoology, and mineralogy allowes comprehensive investigations.

First results of the program were obtained by the joint investigation of a core from Southern Austerngrund, and were published in detail by BeHRE, DÖRJES and IRION in 1984; they will be resumed here. The core A 521 was gained with a vibrocorer at $53^{\circ} 44,5^{\prime} \mathrm{N}$ and $4^{\circ} 30^{\prime} \mathrm{E}$ and had a length of $2.48 \mathrm{~m}$. At the bottom, i. e. 42.68 to $42.48 \mathrm{~m}$ below mean sea-level, a sequence of peat and limnic sediments were met, which were followed by brackisch and marine sediments, deposited under calm conditions without any erosion in between. This favourable situation (that was met with only once beside many failures) provided a reliable fixed point for the sealevel curve, marking exactly the contact zone of the transgression. For a later period a hiatus could be demonstrated which is overlain by the young sea sand (see fig. 1).

\section{Reconstruction and dating of the freshwater environment at the basis}

The core did not penetrate the organic layer as far as the pleistocene subsoil, so the profile starts with reed peat $2.48 \mathrm{~m}$ below the sea bottom and changes at $2.37 \mathrm{~m}$ to freshwater mud until $2.28 \mathrm{~m}$. For these $20 \mathrm{~cm}$ a pollen diagram was elaborated and macrofossil analysis yielded many additional plant remains. The vegetation was dominated by Typha (more than 700 seeds), Phragmites, Juncus effusus, and Sphagnum. Many other reed and swamp species, for example Alisma plantago-aquatica, Carex pseudocyperus, Filipendula ulmaria, Lycopus europaeus, Menyanthes trifoliata, and Solanum dulcamara as well as water plants like Ceratophyllum demersum, Potamogeton pectinatus, and Nymphaea alba were traced by their fruits resp. seeds. Evidently the biotope started with reed swamp and changed gradually to open water, freshwater conditions still remaining. The freshwater mud already contains some foraminifers, thus showing the first indication of the approaching sea.

Pollen analysis and macro-remains also provided the composition of the forest around the site. Pinus sylvestris and Corylus have been the prevailing species, further components were Betula pendula, B. pubescens, and Populus tremula. In the course of the peat formation the thermophilous trees Ulmus and Quercus and later also Alnus invaded and became members of the forest community.

From the pollen diagram of the organic sequence a reliable dating was obtained. Though this layer was rather thin the pollen diagram shows a clear vegetational development that certainly lasted several centuries. Within this time span Corylus reached its characteristic maximum, and the spreading of the thermophilous trees Ulmus and Quercus took place. The upper part of the diagram shows also the immigration of Alnus and first traces of Tilia pollen.

In this phase of vegetational history there are no problems with the dating. The whole sequence has to be placed into the Boreal period. The sharp increase of hazel to its maximum of about $80 \%$ of $\mathrm{AP}$ at $\mathrm{cm} 243$ is the criterium for the boundary $\mathrm{Va} / \mathrm{Vb}$ (after FiRBAS 1949). On the continent this boundary is drawn at $6800 \mathrm{BC}$ ( = $8750 \mathrm{BP}$ ). 


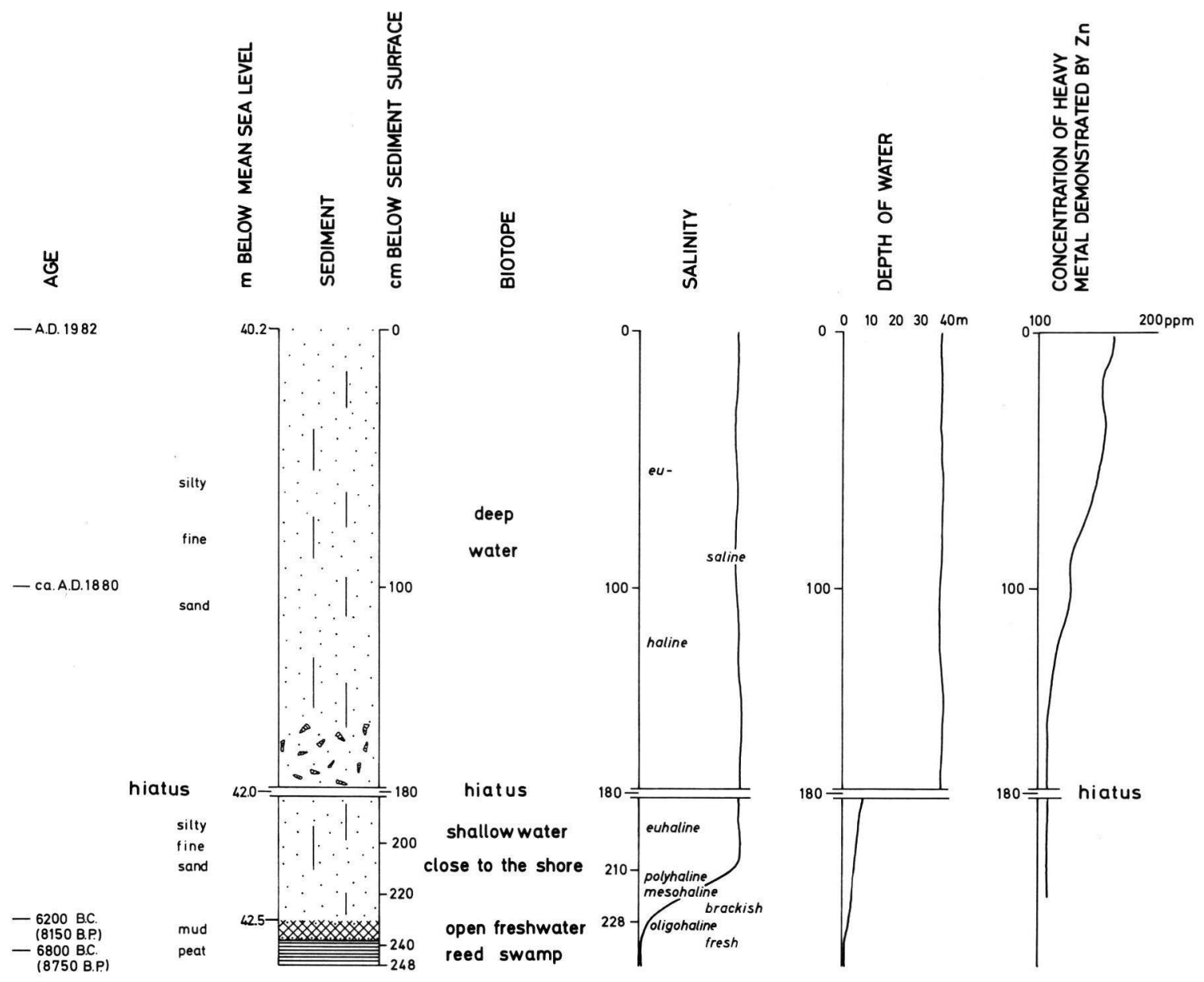

Fig. 1: Summarized palaeo-ecology of Southern Austerngrund, obtained by core A 521.

Prof. M. A. GeYH supplied a ${ }^{14} \mathrm{C}$-date of the peat from core A 521 at this level, which turned out to be $8750 \pm 110 \mathrm{BP}(\mathrm{Hv} 12092)$ and fully supports the pollen analytic date. By further comparison with continental pollen diagrams it can be claimed that the transgression contact itself, the position of which is $14 \mathrm{~cm}$ higher, has to be put at the end of the Boreal period immediately before the main increase of the Alnus curve i.e. the start of the Atlantic period. This means that the transgression took place at about $8150{ }^{14} \mathrm{C}$-years $\mathrm{BP}$ at a position of $42,5 \mathrm{~m}$ below mean sea-level.

From the North Sea there are only very few transgression contacts that can be dated to Boreal age or older (see BEHRE, DÖRJES and IRION 1984) for comparison. In spite of some inaccuracies in getting and dating the exact contact zone and concerning the exact depth of some cores, the positions fit into the sea level curve given by LUDWIG, MÜLLER and STREIF (1979), which indicates a very steep rise of the sea-level between 9000 and 7000 years BP. 


\section{Reconstruction of the brackish and marine environments by the analysis of dead shells in the upper layers of the core}

Above the basic layers of peat and freshwater mud, shell containing sediments start in a core-depth of $228 \mathrm{~cm}$. The deposits up to $210 \mathrm{~cm}$ are marked by adults of common tidal flat species and some juvenils of species inhabiting the shallow sublitorial. Specimens of Hydrobia ulvae, Cerastoderma edule, Macoma balthica, Venus striatula, and Tellina fabula have been identified. Freshwater species and occupants of oligohaline environments are totally absent. Most of the recognized species are known from meso-, poly-, and euhaline waters. The composition of the community identifies the environment as a shallow and calm nearshore locality.

The tidal flat and shallow shelf species Cerastoderma edule, Hydrobia ulvae, Macoma baltbica, Mytilus edulis, and Venus striatula reach their highest abundance in different layers between a sediment depth of 210 and $180 \mathrm{~cm}$. The composition of species and the muddy sediments refer to a nearshore shallow environment without strong currents and surf activity. The numerous specimens and the high percentage of adults are typical of areas with high productivity and poor sedimentation rates.

Above the core-depth of $180 \mathrm{~cm}$ the number of tidal flat and shallow shelf species decreases very rapidly. Between $175 \mathrm{~cm}$ and $155 \mathrm{~cm}$ the deep water species Corbula gibba and Turritella communis reach optimal abundances. The sudden change from shallow water species to deep water species is probably due to a long hiatus at a sediment depth of $180 \mathrm{~cm}$. During this interval the sea-level obviously rose rapidly. As a consequence the environment became euhaline and situated far offshore. The sedimentation rate and the water turbulence were low.

The decrease of specimens in the sediment column between $150 \mathrm{~cm}$ and $100 \mathrm{~cm}$ is probably due to an increase of sedimentation because the decreasing production of biomass cannot be referred to some kind of deterioration in the marine environment. The assumption of an increasing sedimentation is supported by the fact that the uppermost $100 \mathrm{~cm}$ of the sediments were deposited in only one century as the measurements of heavy metals show.

\section{Mineralogy and heavy metals}

Neglecting the calcium contents which predominantly derives from faunal shell material, the mineralogical investigations showed no fundamental changes within the profile. The clay mineral fraction is dominated by illite, followed by kaolinite, and finally, with considerably lower amounts, chlorite and montmorillonite. The coarse fraction consists of quartz, some feldspars, and calcite (which is derived from shells). The correspondence of the mineralogical composition of the single grainsize-fractions from the sediment core with those of two other sediment cores from Skagerrak, which were described by JÖRGENSEN et al. (1981) is surprising. They are also in agreement with our analyses from shorter sediment cores from marine areas on the Danish and Dutch coasts. They differ, however from those from the German Bight. In comparison to the suspended mineralogical load of the rivers which flow into the North Sea (Rivers Rhine, Ems, Weser, and Elbe), the sediments of the core investigated contain some kaolinite and less montmorillonite. The origin of the fine-grained material thus has to be looked 
for elsewhere, not only in the supply by the rivers. Presumably, part of the sediment material was reworked by the Fennoscandian glaciers and later transported to the Austerngrund area by sea-currents.

The mineralogical composition as well as the heavy metals copper, zinc, lead and manganese were analysed with the AAS. It was the purpose of these investigations to determine the degree of pollution of the sediments caused by anthropogenic pollutants in order to obtain information for the dating of the upper part of the core. The depth of the load amounts to about $120 \mathrm{~cm}$ and thus is relatively high. Assuming the animals which live in the sediment do not bury deeper than $20 \mathrm{~cm}$, a sediment layer of $100 \mathrm{~cm}$ thickness has to have been deposited since the beginning of the anthropogenic heavy metal pollution. From the investigation of dated sediment cores it is known that the presence of anthropogenic heavy metals in sediments from our area can be traced back to the year 1880 (MÜLER et al. 1980). With respect to the sediment core investigated, this means that during the last 100 years at least $100 \mathrm{~cm}$ of sediment have been deposited.

\section{References}

Behre, K.-E., Dórjes, J. \& Irion, G. (1984): Ein datierter Sedimentkern aus dem Holozän der südlichen Nordsee. - Probleme der Küstenforschung, 15: 135-148, 6 Abb., 3 Tab.; Hildesheim.

FIRBAS, F. (1949): Spät- und nacheiszeitliche Waldgeschichte Mitteleuropas nördlich der Alpen 1. — Allgemeine Waldgeschichte, 480 S., 157 Abb., 28 Tab.; Jena (Fischer).

Jørgensen, P., Erlenkeuser, H., Lange, H., Nagy, J., Rumohr, J. \& Werner, F. (1981): Sedimentological and stratigraphical studies of two cores from the Skagerrak. - Spec. Publs. int. Ass. Sedimentologists, 5: 397-414, 16 Abb., 2 Tab.; Oxford.

LudwiG, G., Mứler, H. \& StreIF, H. (1979): Neuere Daten zum holozänen Meeresspiegelanstieg im Bereich der Deutschen Bucht. - Geol. Jb., D 32: 3-22, 2 Abb., 7 Tab.; Hannover.

Múluer, G., Dominik, J., Reuther, R., Malisch, R., Schulte, E., Acker, L. \& Irion, G. (1980): Sedimentary Record of Environmental Pollution in the Western Baltic Sea. - Naturwissenschaften, 67: 595-600; Heidelberg.

Manuscript accepted on 15. 10. 1984 
